\title{
Analysis of the cadastral data published in the Polish Spatial Data Infrastructure
}

\author{
Waldemar Izdebski \\ Warsaw University of Technology \\ Faculty of Geodesy and Cartography \\ 1 Pl. Politechniki, 00-661 Warsaw, Poland \\ e-mail: waldemar.izdebski@gmail.com. \\ https://orcid.org/0000-0003-3087-9936
}

Received: 22 June 2017 / Accepted: 22 September 2017

\begin{abstract}
The cadastral data, including land parcels, are the basic reference data for presenting various objects collected in spatial databases. Easy access to up-to-date records is a very important matter for the individuals and institutions using spatial data infrastructure. The primary objective of the study was to check the current accessibility of cadastral data as well as to verify how current and complete they are. The author started researching this topic in 2007, i.e. from the moment the Team for National Spatial Data Infrastructure developed documentation concerning the standard of publishing cadastral data with the use of the WMS. Since ten years, the author was monitoring the status of cadastral data publishing in various districts as well as participated in data publishing in many districts. In 2017, when only half of the districts published WMS services from cadastral data, the questions arise: why is it so and how to change this unfavourable status? As a result of the tests performed, it was found that the status of publishing cadastral data is still far from perfect. The quality of the offered web services varies and, unfortunately, many services offer poor performance; moreover, there are plenty services that do not operate at all.
\end{abstract}

Key words: web services, web map service (WMS), spatial data infrastructure, cadastral data

\section{Spatial data of districts in the National Spatial Data Infrastructure (KIIP)}

Land parcels, the most important theme of spatial data infrastructure are managed in Poland by districts, self-governmental units. They are derived from $380^{1}$ land and property registers maintained also by districts.

1 We do not take into account any potential divisions into separately maintained parts of some of the district-level bases. 
The importance of the theme of land parcels in the Spatial Data Infrastructure results from the fact that a land parcel, in addition to its primary significance concerning land ownership, is also one of the main reference objects used to locate other objects stored in spatial data bases (Oosterom, et al., 2009; Inspire, 2014; Gaździcki, 2016).

With the common use of a land parcel as a reference object, access to services that enable one to change a land parcel number (identifier) into its spatial location (geometry) is a very important matter for creators of spatial information systems. A widely accessible search service, based on up-to-date data, would offer an easy to implement in external IT solutions search egnine for land parcels all over the country. Unfortunately, today it is believed that comprehensive land register bases and services related to them function only in approx. 40\% of district-level units (GUGiK, 2017). In the remaining ones, either no web services exist to ensure access to cadastral data, or sufficient numerical data are unavailable to launch such services.

With such state of affairs, for years to come land registers will be maintained by districts and - by way of addition - different IT systems will be used. This does not mean, however, that at the national level we have put up with such fragmentation and each time determine specific access parameters to district-level bases and then analyse their structure. An effective solution to the problem is using properly standardised - at least two - web services.

One of them is access to the presentation cadastral data in any area (Figure 1), while the other is the possibility to locate any parcel, i.e. obtaining its geometrical specifications, namely an ordered list of coordinates describing the parcel (Figure 2).

In this study, we will focus only on the first service, i.e. the one related to presentation of up-to-date cadastral data for any area in Poland. More information on the service comprising locating land parcels and their addresses can be found in paper Izdebski (2014).

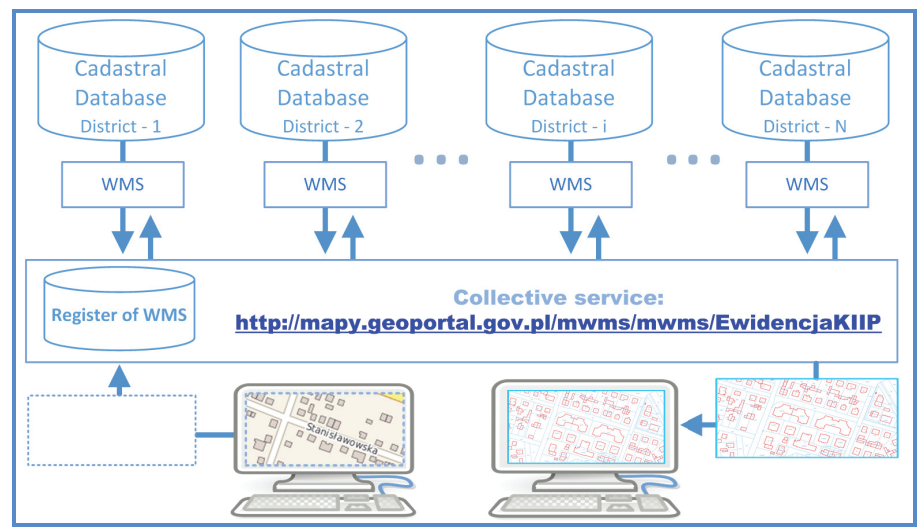

Fig. 1. Conceptual idea of the collective WMS to present land parcels (EwidencjaKIIP) 


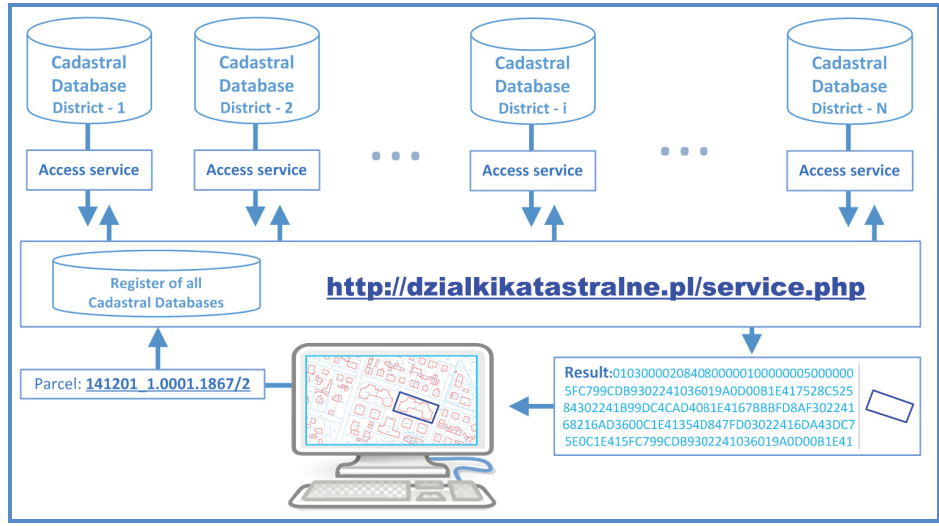

Fig. 2. Conceptual idea of the cadastral parcel locating service

\section{Services of presenting cadastral data}

Work on standardisation of graphic presentation of the cadastral data as part of the WMS commenced in Poland in 2007. It started with the development of rules of presenting basic cadastral data (land parcels and buildings) by the Team for National Spatial Data Infrastructure. The core of the adopted regulations was definition of parameters related to naming and graphic presentation of selected cadastral information available in the WMS. The parameters agreed upon are presented in Table 1, while more information about the Team's work can be found in Izdebski (2016).

Table 1. Parameters of the WMS base layers in district cadastral nodes

\begin{tabular}{|c|c|c|c|}
\hline $\begin{array}{c}\text { Layer title } \\
\text { (Polish letters in UTF-8) }\end{array}$ & $\begin{array}{c}\text { Layer name } \\
\text { (Without Polish letters) }\end{array}$ & Colour RGB & Other parameters \\
\hline Działki (Parcels) & dzialki & $64,160,255$ & Line thickness $=1$ \\
\hline Numery działek (Parcels numbers) & numery_dzialek & $64,160,255$ & Font=Arial, Size=9, Position=cc \\
\hline Budynki (Buildings) & budynki & $200,0,0$ & Line thickness $=2$ \\
\hline
\end{tabular}

Based on the study in question, the Head Office of Geodesy and Cartography (GUGiK) developed the collective WMS available today as the so-called EwidencjaKIIP. The source of data for the service comprises district cadastral databases, also sometimes referred to as district cadastral nodes. Service address: http://mapy.geoportal.gov. $\mathrm{pl} / \mathrm{mwms} / \mathrm{mwms} /$ EwidencjaKIIP. The service was launched on 12 December 2008, under the initial name of "Multisource WMS". It allows one to view the cadastral data (relevant in terms of areas) from the district WMS. Upon launching, the service covered three districts (Koło, Środa Wielkopolska, and Turek); then on 26 May 2009, it was expanded with the following districts: Chełm, Cieszyn, Kościerzyna, Mielec, Mińsk Mazowiecki, Poznań, Pruszków, Strzelce Opolskie, Szczcinek, Ożarów 
Mazowiecki, Wejherowo, Wołomin, and Złotoryja along with the town of Chełm Geoforum.pl (2009).

Over the years, other districts were included in the collective service; according to the data available from the Geodetic and Cartographic Documentation Center (CODGiK), in early 2007 the Ewidencja KIIP service comprised 135 district services, the list of which can be found in Table 2 .

Table 2. A list of districts in the EwidencjaKIIP service

\begin{tabular}{|c|c|c|c|c|c|c|c|}
\hline No. & TERYT & Name & Status & No. & TERYT & Name & Status \\
\hline 1 & 0401 & Aleksandrów Kujawski & operating & 69 & 2814 & Olsztyn & operating \\
\hline 2 & 1001 & Bełchatów & operating & 70 & 2606 & Opatów & non-operating \\
\hline 3 & 0661 & city of Biała Podlaska & operating & 71 & 1007 & Opoczno & operating \\
\hline 4 & 1401 & Białobrzegi & operating & 72 & 1661 & city of Opole & operating \\
\hline 5 & 2061 & Białystok & operating & 73 & 0612 & $\begin{array}{l}\text { Opole (lubelskie } \\
\text { province) }\end{array}$ & non-operating \\
\hline 6 & 2402 & Bielsko-Biała & operating & 74 & 1461 & city of Ostrołęka & operating \\
\hline 7 & 2461 & city of Bielsko-Biała & operating & 75 & 2607 & Ostrowiec Świętokrzyski & operating \\
\hline 8 & 0602 & Biłgoraj & operating & 76 & 3017 & Ostrów Wielkopolski & operating \\
\hline 9 & 1202 & Brzesko & operating & 77 & 2815 & Ostróda & operating \\
\hline 10 & 1021 & Brzeziny & operating & 78 & 1417 & Otwock & operating \\
\hline 11 & 0662 & city of Chełm & operating & 79 & 0613 & Parczew & operating \\
\hline 12 & 3001 & Chodzież & operating & 80 & 1418 & Piaseczno & operating \\
\hline 13 & 3202 & Choszczno & operating & 81 & 3019 & Piła & operating \\
\hline 14 & 2403 & Cieszyn & operating & 82 & 1010 & Piotrków Trybunalski & operating \\
\hline 15 & 2404 & Częstochowa & operating & 83 & 2608 & Pińczów & operating \\
\hline 16 & 1803 & Dębica & operating & 84 & 3020 & Pleszew & non-operating \\
\hline 17 & 3203 & Drawsko Pomorskie & non-operating & 85 & 3211 & Police & operating \\
\hline 18 & 0202 & Dzierżoniów & operating & 86 & 3021 & Poznań & operating \\
\hline 19 & 1403 & Garwolin & operating & 87 & 1610 & Prudnik & operating \\
\hline 20 & 0203 & Głogów & operating & 88 & 1421 & Pruszków & operating \\
\hline 21 & 0801 & Gorzów Wlkp. & operating & 89 & 1422 & Przasnysz & operating \\
\hline 22 & 0861 & $\begin{array}{l}\text { city of Gorzów } \\
\text { Wielkopolski }\end{array}$ & operating & 90 & 0614 & Puławy & operating \\
\hline 23 & 3004 & Gostyń & operating & 91 & 3212 & Pyrzyce & operating \\
\hline 24 & 0204 & Góra & operating & 92 & 1425 & Radom & operating \\
\hline 25 & 1405 & Grodzisk Mazowiecki & operating & 93 & 0615 & Radzyń Podlaski & operating \\
\hline 26 & 3205 & Gryfice & operating & 94 & 1013 & Rawa Mazowiecka & operating \\
\hline 27 & 0605 & Janów Lubelski & operating & 95 & 1815 & Ropczyce & operating \\
\hline 28 & 2467 & city of Jastrzębie-Zdrój & operating & 96 & 2472 & city of Ruda Śląska & operating \\
\hline 29 & 0205 & Jawor & operating & 97 & 0412 & Rypin & operating \\
\hline 30 & 0261 & city of Jelenia Góra & operating & 98 & 1816 & Rzeszów & operating \\
\hline
\end{tabular}




\begin{tabular}{|c|c|c|c|c|c|c|c|}
\hline No. & TERYT & Name & Status & No. & TERYT & Name & Status \\
\hline 31 & 2602 & Jędrzejów & operating & 99 & 1863 & city of Rzeszów & operating \\
\hline 32 & 3007 & Kalisz & operating & 100 & 1464 & city of Siedlce & operating \\
\hline 33 & 3207 & Kamień Pomorski & operating & 101 & 1426 & Siedlce & non-operating \\
\hline 34 & 2603 & Kazimierza Wielka & operating & 102 & 2474 & $\begin{array}{l}\text { city of Siemianowice } \\
\text { Śląskie }\end{array}$ & operating \\
\hline 35 & 2604 & Kielce & operating & 103 & 2010 & Siemiatycze & operating \\
\hline 36 & 1604 & Kluczbork & operating & 104 & 1063 & city of Skierniewice & non-operating \\
\hline 37 & 0208 & Kłodzko & operating & 105 & 1015 & Skierniewice & operating \\
\hline 38 & 1806 & Kolbuszowa & operating & 106 & 0805 & Stubice & operating \\
\hline 39 & 3009 & Koło & operating & 107 & 1818 & Stalowa Wola & operating \\
\hline 40 & 2605 & Końskie & operating & 108 & 2612 & Staszów & operating \\
\hline 41 & 3010 & Konin & operating & 109 & 0806 & Strzelce Krajeńskie & operating \\
\hline 42 & 2206 & Kościerzyna & operating & 110 & 1819 & Strzyżów & operating \\
\hline 43 & 1407 & Kozienice & operating & 111 & 0807 & Sulęcin & operating \\
\hline 44 & 0606 & Krasnystaw & operating & 112 & 3024 & Szamotuły & non-operating \\
\hline 45 & 1002 & Kutno & operating & 113 & 3215 & Szczecinek & non-operating \\
\hline 46 & 1408 & Legionowo & non-operating & 114 & 2817 & Szczytno & operating \\
\hline 47 & 0262 & city of Legnica & operating & 115 & 0218 & Środa Wielkopolska & operating \\
\hline 48 & 1821 & Lesko & operating & 116 & 3263 & city of Świnoujście & operating \\
\hline 49 & 1809 & Lubaczów & operating & 117 & 1864 & city of Tarnobrzeg & operating \\
\hline 50 & 2407 & Lubliniec & operating & 118 & 1820 & Tarnobrzeg & operating \\
\hline 51 & 1810 & Lańcut & operating & 119 & 1217 & Zakopane & operating \\
\hline 52 & 1003 & Lask & operating & 120 & 0463 & city of Toruń & operating \\
\hline 53 & 0610 & Łęczna & operating & 121 & 3027 & Turek & operating \\
\hline 54 & 3218 & Łobez & operating & 122 & 1218 & Wadowice & operating \\
\hline 55 & 1410 & Łosice & operating & 123 & 1432 & Ożarów Mazowiecki & non-operating \\
\hline 56 & 1005 & Lowicz & operating & 124 & 3028 & Wągrowiec & operating \\
\hline 57 & 1811 & Mielec & operating & 125 & 2215 & Wejherowo & operating \\
\hline 58 & 3014 & Międzychód & operating & 126 & 0464 & city of Włocławek & operating \\
\hline 59 & 2408 & Mikołów & operating & 127 & 0619 & Włodawa & operating \\
\hline 60 & 1412 & Mińsk Mazowiecki & operating & 128 & 3029 & Wolsztyn & operating \\
\hline 61 & 2008 & Mońki & operating & 129 & 1434 & Wołomin & operating \\
\hline 62 & 3210 & Myślibórz & operating & 130 & 3030 & Września & operating \\
\hline 63 & 1606 & Namysłów & operating & 131 & 0812 & Wschowa & operating \\
\hline 64 & 1414 & Nowy Dwór Mazowiecki & operating & 132 & 0620 & Zamość & operating \\
\hline 65 & 2812 & Nowe Miasto Lubawskie & operating & 133 & 0226 & Złotoryja & non-operating \\
\hline 66 & 3015 & Nowy Tomyśl & non-operating & 134 & 1436 & Zwoleń & operating \\
\hline 67 & 1607 & Nysa & operating & 135 & 0811 & Żary & operating \\
\hline 68 & 1608 & Olesno & operating & & & & \\
\hline
\end{tabular}


Since there have been many issues with using the district services, it was decided that a closer look will be given to all WMS included in the collective service of EwidencjaKIIP and that their availability and performance of functioning should be checked.

First, however, an important comment needs to be made on the collective service of EwidencjaKIIP, which in GetCapabilities request returns a rather poor section $<$ Abstract $>$. The section contains only the record: $<$ Abstract $>$ Integracja ustug KIIP $<1$ Abstract $>$. Such information is of no use to uninitiated users; thus, it hinders the effective and extensive use of the service. It would better for the users if the record $<$ Abstract $>$ was modified at least to the following form:

"The Ewidencja KIIP" service is a collective service comprising presentation of cadastral data directly from the level of district units. The service only contains data of the units that have their own WMS of required parameters and incorporated their WMS into the 'Ewidencja KIIP' collective service."

The analysis of district services started off with a general overview of them, with the focal point being verification whether given services can indeed be found under provided addresses. In the end, the analysis carried out on 22 May 2017, from 9:00 am to 11:00 am, showed that 12 of the 135 reported services were inactive, while in other several services various issues were encountered that prevented their use. It is natural then that the basic assessment criterion for the district WMS is its availability (functioning): to put it simply, if a service does not work it is impossible to assess its parameters.

With respect to the operating services, one can distinguish several detailed assessment criteria to compare them and then point to corrective actions that should be taken to improve the functioning of faulty services. Based on the author's experience comprising frequent use of the district WMS as well as creation and supervision of functioning thereof, the following criteria were established to assess the district WMS:

1. availability of a service under a given address,

2. completeness of data presented by the service,

3. currency of data presented by the service,

4. compliance of presentation with the adopted standard,

5. performance.

The first criterion is indisputable and meeting it is the basis for any further research; to be able to assess a service it needs to be operating and have its own URL under which it can be found. It is important that the address is permanent since it is entered into configuration of the EwidencjaKIIP collective service; each time a reference indicates a given district the collective service will call the address (Figure 1). Another solution would be to make sure changing an address is easy for the providers on the district level. In this case, however, a service would have to be established where the providers of district services would need to notify of any changes in their address, while the staff of the organisation rendering the collective service available, upon receiving of such notification and having tested it in the district service for compliance with the expected parameters, would disable the old address and enable the new one. 
Yet another solution would be automation of the process to enable the districts to reconfigure their services in the collection service on their own, but in this case the supervising organisation would have to share relevant software to test the new service parameters and to allow for changes to be introduced only if specific conditions have been fulfilled.

The issue of supervising the collective service is crucial in the functioning of any services which integrate data and distributed services; the issue needs to be treated seriously if we want the collective services to fulfil their roles and establish themselves in general applications.

\section{Detailed research on the district WMS}

Detailed research on the services set off with checking their availability. In consequence, it was found that 12 addresses are non-responsive. The services of the following districts were beset with problems: Drawsko Pomorskie, Legionowo, Nowy Tomyśl, Opatów, Opole, Pleszew, Siedlce, Szamotuły, Szczecinek, Ożarów Mazowiecki, Złotoryja, as well as the city of Skierniewice. The analysis result was taken into account in Table 2 with an entry non-operating for disabled services or operating for active services. The analysis result does not mean that the districts mentioned above do not share the WMS; it means that under the address reported to the collective service of EwidencjaKIIP no response was obtained at the moment of testing. This purports that the districts are not fully aware that once the WMS has been incorporated into the collective service one should take care of its proper functioning. The situation shows that the quality of the collective service is of little concern to the supervising organisation, namely CODGiK.

Next stage was about researching only 123 district services, namely they were tested in terms of completeness of presented data. As the result of the research the services were discovered which only partially cover the district area with land parcels; a sample of this is presented in Figure 3 based on the data from the Kielce district.

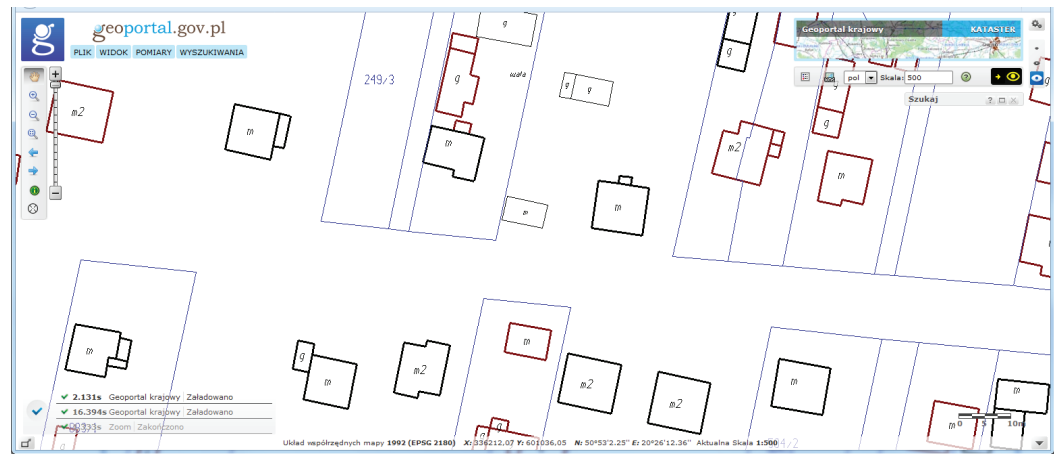

Fig. 3. Sample of the WMS with incomplete data 
The first reaction to this piece of information is the conclusion that such services should not be part of the collective service as they may create confusion. Unfortunately, such situations stem from the lack of adequate quality of data in the entire district; this is impossible to correct overnight. In the author's opinion, districts should be appreciated for publishing even fractional data rather than waiting for obtaining correct data for the whole of the district, while making attempts at successive expansion of the area covered by the published data. In other words, fractional data are more useful than no data at all. However, in such cases, it seems worthwhile to emphasise that the service in a district is incomplete in terms of data and correct the presentation method so that the user is aware that the data he or she obtains are not complete. At the time of the analysis, there were 20 districts which published incomplete cadastral data. The results are presented in the summary Table 3 with the entries of "+" or "-." in Completeness column.

Next, the published WMS data were verified in terms of their compatibility with the adopted standard, developed in 2007 by the Team for National Spatial Data Infrastructure. As a result of the actions taken it was confirmed that nearly all services are compliant with the adopted standard as far as their presentation is concerned; also, the cases of deviances are so marginal that they are not worth discussing.

One should mention here, however, that adequate information is missing in the $<$ Service $>$ section of the XML file returned for GetCapabilities requests sent to district authorities. In the opinion of the author, this section should contain at least basic information about the service related with the $<$ Abstract $>$ tag used to place a short description of the service, and with the $<$ ContactInformation $>$ tag used to place such contact information as $<$ ContactOrganization $>,<$ ContactAddress $>$, $<$ ContactElectronicMailAddress $>$ or $<$ ContactVoiceTelephone $>$.

A positive example (Figure 4) comprises the WMS from the Mińsk Mazowiecki, Pruszków or Wołomin districts, which have the information discussed above, although the Description section ( $<$ Abstract $>$ tag) could use more information.

\begin{tabular}{|ll}
\hline \multicolumn{2}{|l}{ Informacje o usłudze } \\
$\begin{array}{ll}\text { Opis } & \text { Serwis danych wMS PODGIK Minsk Maz } \\
\text { Organizacja } & \text { Powiatowy Osrodek Dokumentacji Geodezyjnej i Kartograficznej Minsk Mazowiecki } \\
\text { Adres } & \text { Kosciuszki } 3 \text { mazowieckie 05-300 Minsk Mazowiecki Poland } \\
\text { Telefon } & +48257598747 \\
\text { E-mail } & \text { minsk@igeomap.pl }\end{array}$ \\
\hline
\end{tabular}

Fig. 4. An example of information about the WMS from the Mińsk Mazowiecki district displayed on geoportal.gov.pl

The data currency criterion is not as easy to verify as the preceding criteria. This is due to the fact that one cannot derive the currency of the data source from the standard information returned in the WMS. One should bear in mind that the WMS is oftentimes based on replicas of data bases of various currency, for different reasons 
such as security or organisation. Information about currency is very much needed to assess usefulness of the service, therefore one should add to the values returned by GetCapabilities a section ExtendedCapabilities (Figure 5) which is recommended in the specifications for INSPIRE browsing service (Inspire, 2011) and modify it after every data update on which the service relies, by filling out at least the $<$ DateOfLastRevision $>$ box.

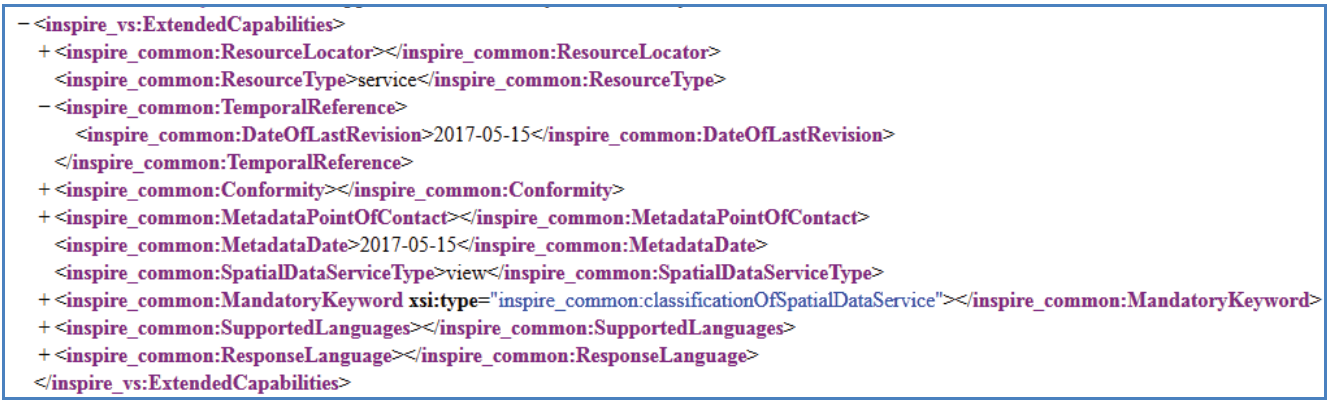

Fig. 5. Extended section in GetCapabilities (Mińsk Mazowiecki district)

The existence of such an extension is particularly important for monitoring the way the services function as it offers a possibility to inquire the district services about the date of the recent data update and take proper action if the data is not updated at all. At this point the ExtendedCapabilities section can only be found in the services provided by the Geo-System Sp. z o. o. Company.

The last stage of the tests was verification of service performance, which was performed by making 10 GetMap requests to each service with alternating areas. The best response times were 0.1 second, but some services offered response only after several seconds. The most (10) points were awarded to the fastest services, with respectively fewer points being assigned to slower services. The scores were placed in Table 3 in the Performance column. 


\begin{tabular}{|c|c|c|c|c|c|c|c|c|c|c|c|c|c|c|c|c|c|c|c|}
\hline Performance & a & r & $\infty$ & t & r & r & r & $\infty$ & $m$ & r & - & $\infty$ & - & 0 & $\infty$ & t & $\infty$ & - & $\nabla$ \\
\hline Completeness & + & + & + & + & ' & + & + & + & + & + & + & + & ' & + & + & + & ' & ' & + \\
\hline 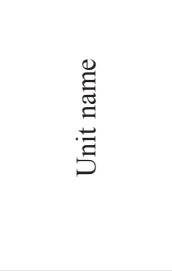 & 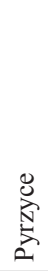 & 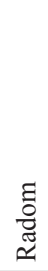 & 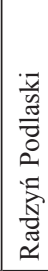 & 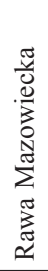 & 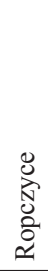 & 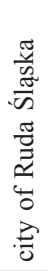 & 离 & 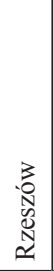 & 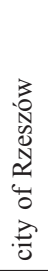 & 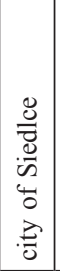 & 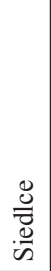 & 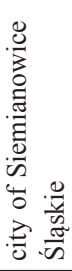 & 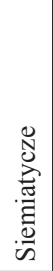 & 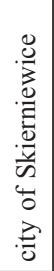 & 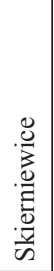 & 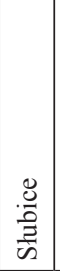 & 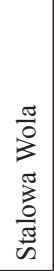 & 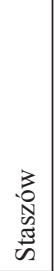 & 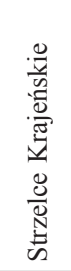 \\
\hline TERYT & $\underset{m}{\stackrel{\sim}{\sim}}$ & $\stackrel{\text { Iิ }}{\mathcal{I}}$ & $\frac{n}{8}$ & $\stackrel{m}{\circ}$ & $\stackrel{\infty}{\infty}$ & $\underset{\sim}{\stackrel{\sim}{\sim}}$ & $\frac{\mathfrak{T}}{\mathrm{d}}$ & $\stackrel{0}{\infty}$ & $\begin{array}{l}\qquad \\
\infty \\
\infty\end{array}$ & $\begin{array}{l}\text { d } \\
\pm\end{array}$ & $\begin{array}{l}\stackrel{J}{ \pm} \\
\end{array}$ & 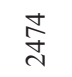 & $\stackrel{ }{\stackrel{2}{\sim}}$ & $\stackrel{\widehat{\varrho}}{\varrho}$ & $\stackrel{n}{\circ}$ & $\begin{array}{l}n \\
\infty \\
\infty\end{array}$ & $\stackrel{\infty}{\infty}$ & $\underset{\sim}{\stackrel{\sim}{\sim}}$ & $\begin{array}{l}\stackrel{0}{0} \\
\stackrel{0}{\circ}\end{array}$ \\
\hline$\dot{z}$ & $\infty$ & \$ & $\infty$ & $\infty$ & $\infty$ & $\infty$ & $\infty$ & ฉ & $\bar{a}$ & ส & $\kappa$ & む゙ & 2 & ஃ & $\hat{a}$ & $\stackrel{\infty}{\circ}$ & à & 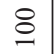 & $\Xi$ \\
\hline Performance & $m$ & 으 & - & ナ & a & $\infty$ & $a$ & t & $\infty$ & $a$ & 6 & t & 6 & t & t & 으 & t & r & $\infty$ \\
\hline Completeness & + & + & + & ' & ' & + & + & + & + & + & + & + & + & + & + & + & ' & + & + \\
\hline 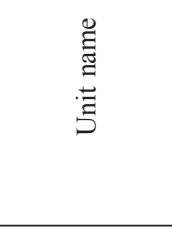 & 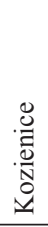 & 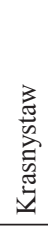 & 昙 & 总 & 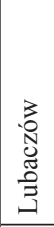 & 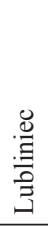 & 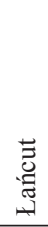 & 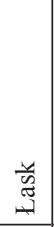 & స్ّ & $\begin{array}{l}\mathrm{N} \\
\text { ه్ } \\
0 \\
\end{array}$ & 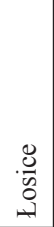 & لَّ & $\frac{\mathscr{J}}{\stackrel{\Xi}{\Xi}}$ & 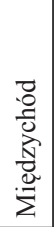 & 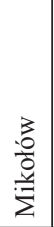 & 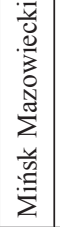 & $\begin{array}{l}\bar{y} \\
\Sigma \overline{0}\end{array}$ & 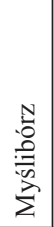 & 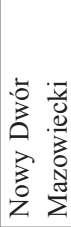 \\
\hline TERYT & 宇 & : & 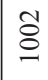 & $\vec{\infty}$ & $\stackrel{\odot}{\infty}$ & 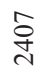 & $\stackrel{\circ}{\infty}$ & $\stackrel{\varepsilon}{\varepsilon}$ & $\stackrel{\circ}{\circ}$ & $\underset{⿱ \pi}{\stackrel{\infty}{d}}$ & $\stackrel{ }{\stackrel{ }{\Xi}}$ & $\stackrel{\wp}{\varrho}$ & $\underset{\sim}{\vec{\infty}}$ & $\underset{\vec{D}}{\vec{D}}$ & $\stackrel{\infty}{\stackrel{+}{+}}$ & $\underset{\exists}{\exists}$ & $\underset{\sim}{\infty}$ & $\underset{\sim}{\stackrel{ }{\pi}}$ & $\underset{\Xi}{\stackrel{\Xi}{\Xi}}$ \\
\hline$\dot{z}$ & $\underset{\mathcal{Y}}{\widetilde{\gamma}}$ & 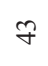 & 寸 & q & fo & F & $\stackrel{\infty}{+}$ & gे & 오 & $\bar{n}$ & in & $n$ & in & $n$ & $i$ & $i n$ & $\stackrel{\infty}{n}$ & in & 8 \\
\hline Performance & $m$ & t & $a$ & + & N & a & 으 & $\infty$ & - & $\infty$ & 으 & a & 으 & $m$ & $\infty$ & $\infty$ & 으 & 으 & t \\
\hline Completeness & + & ' & + & + & + & + & + & ' & + & + & + & + & + & + & + & 1 & + & + & + \\
\hline 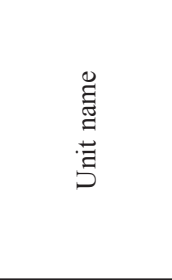 & 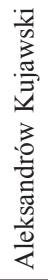 & 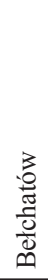 & 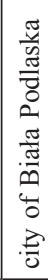 & 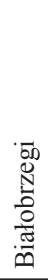 & $\begin{array}{l}\frac{y}{0} \\
\frac{0}{0} \\
\frac{0}{n} \\
0\end{array}$ & 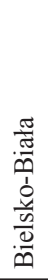 & 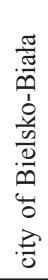 & 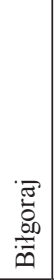 & $\begin{array}{l}\frac{9}{0} \\
\text { N } \\
\text { ص }\end{array}$ & 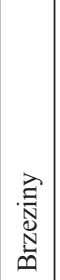 & 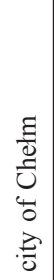 & 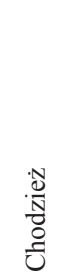 & 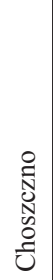 & 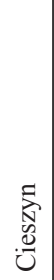 & 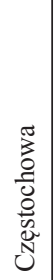 & $\begin{array}{l}\stackrel{\widetilde{0}}{0} \\
\stackrel{0}{0} \\
0\end{array}$ & 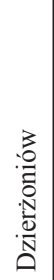 & 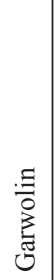 & $\begin{array}{l}3 \\
\text { 总 } \\
\text { 잉 } \\
0\end{array}$ \\
\hline TERYT & 宫 & $\overline{8}$ & $\overrightarrow{8}$ & 定 & ఫ্ঠ & $\stackrel{\text { ò }}{\stackrel{\sim}{\sim}}$ & $\underset{\stackrel{0}{+}}{\sim}$ & ¿̊ & 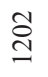 & $\overrightarrow{\widehat{\sigma}}$ & त్ & 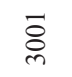 & $\begin{array}{c}\text { ָे } \\
\text { }\end{array}$ & 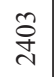 & $\underset{+}{\stackrel{+}{+}}$ & $\begin{array}{c}0 \\
\stackrel{\infty}{0}\end{array}$ & $\begin{array}{l}\text { ¿े } \\
\text { ठ }\end{array}$ & ồ & ڤి \\
\hline$\dot{0}$ & - & $\sim$ & $m$ & $\nabla$ & $n$ & 6 & $r$ & $\infty$ & $a$ & 으 & $=$ & $\simeq$ & 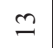 & \pm & $\cong$ & $\mathscr{0}$ & 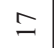 & $\stackrel{\infty}{-}$ & 2 \\
\hline
\end{tabular}




\begin{tabular}{|c|c|c|c|c|c|c|c|c|c|c|c|c|c|c|c|c|c|c|c|c|c|}
\hline$\nabla$ & $n$ & $r$ & - & $\stackrel{0}{0}$ & in & 6 & $m$ & $\infty$ & $\infty$ & - & $\circ$ & $\stackrel{0}{ }$ & $\infty$ & $\circ$ & $\infty$ & $\sim$ & $a$ & in & $\nabla$ & $\infty$ & $\nabla$ \\
\hline+ & + & + & + & + & + & + & + & + & + & + & + & + & + & + & + & + & + & + & + & + & + \\
\hline 亮 & $\begin{array}{l}\text { 意 } \\
\stackrel{\Xi}{\Xi}\end{array}$ & 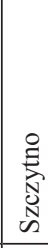 & 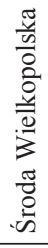 & 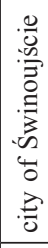 & 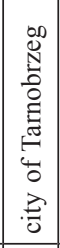 & 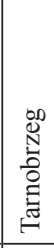 & $\begin{array}{l}\text { ज्ञ } \\
\text { Оू. } \\
\text { 产 } \\
\text { N. }\end{array}$ & 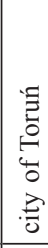 & 弟 & $\begin{array}{l}\frac{8}{0} \\
\frac{0}{3} \\
\frac{0}{\pi} \\
3\end{array}$ & 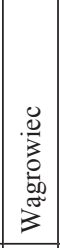 & $\frac{0}{0}$ & 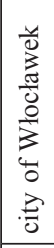 & $\begin{array}{l}\frac{\pi}{3} \\
\frac{\pi}{8} \\
3\end{array}$ & $\begin{array}{l}\text { 勇 } \\
\frac{0}{0} \\
0 \\
3\end{array}$ & 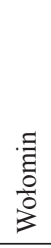 & 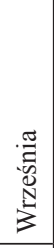 & \begin{tabular}{|l|} 
\\
0 \\
0 \\
0 \\
0 \\
0 \\
0 \\
3 \\
\end{tabular} & 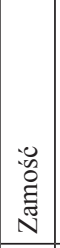 & $\begin{array}{l}\frac{0}{0} \\
0 \\
\frac{3}{N}\end{array}$ & . \\
\hline$\stackrel{\vec{\infty}}{\sigma}$ & $\hat{\infty}$ & 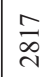 & $\frac{\infty}{\widetilde{\delta}}$ & $\begin{array}{l}\hat{0} \\
\text { लै }\end{array}$ & \begin{tabular}{l}
\multirow{0}{0}{} \\
$\infty$
\end{tabular} & $\begin{array}{l}\text { న్ } \\
\infty\end{array}$ & $\stackrel{\Xi}{\simeq}$ & $\begin{array}{l}\hat{o} \\
\hat{0}\end{array}$ & స్ & $\stackrel{\infty}{\stackrel{(}{\beth}}$ & 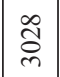 & $\frac{n}{\sqrt{d}}$ & 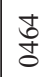 & $\frac{a}{8}$ & ָे & $\stackrel{+}{\stackrel{\Xi}{ \pm}}$ & లి & $\frac{N}{\infty}$ & ণ్రి & $\begin{array}{l}\stackrel{\oplus}{ \pm} \\
\stackrel{\oplus}{+}\end{array}$ & $\bar{\infty}$ \\
\hline ฮิ & $\hat{\varrho}$ & $\stackrel{ \pm}{\circ}$ & $\stackrel{\imath}{\varrho}$ & 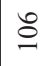 & $\hat{\circ}$ & $\stackrel{\infty}{\varrho}$ & $\stackrel{8}{\circ}$ & $\stackrel{\varrho}{=}$ & $\exists$ & $\cong$ & $\stackrel{\cong}{=}$ & $\stackrel{\Xi}{\Xi}$ & $\cong$ & $\stackrel{0}{=}$ & $\Xi$ & $\stackrel{\infty}{=}$ & $\stackrel{\varrho}{\exists}$ & $\stackrel{\text { తి }}{ }$ & $\vec{\beth}$ & ป & $\tilde{\Xi}$ \\
\hline ナ & 으 & 응 & $\sigma$ & $\nabla$ & a & in & $m$ & 은 & $\nabla$ & $\circ$ & $m$ & $a$ & 으 & $\nabla$ & $r$ & $a$ & $a$ & $a$ & 으. & $n$ & $\infty$ \\
\hline+ & + & + & + & + & + & + & ' & ' & + & + & + & + & + & + & + & + & + & + & + & + & + \\
\hline 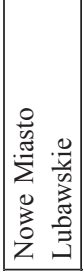 & 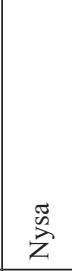 & $\frac{\stackrel{0}{0}}{\frac{0}{0}}$ & $\begin{array}{l}\text { 敢 } \\
\text { a } \\
0\end{array}$ & $\begin{array}{l}\text { đั. } \\
\text { ठे } \\
\text { ठे }\end{array}$ & 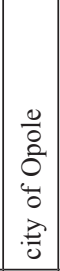 & 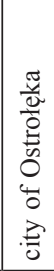 & 竞 & $\begin{array}{l}\frac{\bar{y}}{v} \\
0 \\
0 \\
0 \\
0 \\
0 \\
0 \\
0 \\
0 \\
0 \\
0 \\
0 \\
0\end{array}$ & 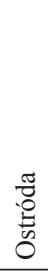 & $\begin{array}{l}\text { y. } \\
\text { ऐo } \\
0\end{array}$ & 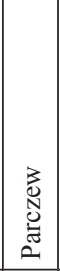 & 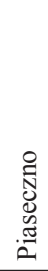 & $\frac{\pi}{\overrightarrow{0}}$ & 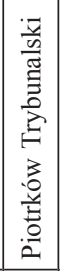 & 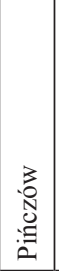 & $\begin{array}{l}\stackrel{0}{0} \\
\stackrel{0}{0}\end{array}$ & $\begin{array}{l}\text { जี } \\
\text { సี } \\
\text { م }\end{array}$ & $\begin{array}{l}\text { 首 } \\
\text { 吾 }\end{array}$ & 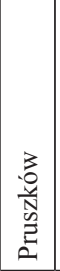 & 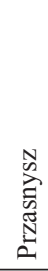 & $\frac{\vec{c}}{\vec{E}}$ \\
\hline$\underset{\infty}{\stackrel{\sim}{\sim}}$ & $\stackrel{0}{0}$ & $\stackrel{\infty}{0}$ & $\underset{\sim}{\Delta}$ & $\hat{\varnothing}$ & $\underset{0}{0}$ & 宫 & : & $\stackrel{n}{\vec{n}}$ & $\frac{n}{\infty}$ & $\stackrel{\Xi}{\exists}$ & $\frac{m}{b}$ & $\frac{\infty}{\exists}$ & 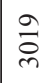 & $\stackrel{0}{\circ}$ & $\begin{array}{l}\infty \\
\stackrel{d}{0} \\
\sim\end{array}$ & $\underset{m}{\bar{n}}$ & ఫ్రి & $\stackrel{0}{0}$ & $\overrightarrow{\mathcal{I}}$ & ָ̃ & $\frac{ \pm}{8}$ \\
\hline $\bar{\sigma}$ & రె & $\widehat{6}$ & $\mathbb{J}$ & 6 & 8 & $\hat{\sigma}$ & $\approx$ & 8) & $\stackrel{R}{R}$ & $\nabla$ & $\mathbb{N}$ & 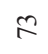 & $\underset{⿱}{+}$ & $\cong$ & $\stackrel{0}{2}$ & $\approx$ & $\stackrel{\infty}{\sim}$ & 2 & $\triangleright$ & $\bar{\infty}$ & $\infty$ \\
\hline$\infty$ & $a$ & 은 & $m$ & $\infty$ & 은 & $m$ & t & $\infty$ & $a$ & $m$ & $\nabla$ & $a$ & $N$ & $m$ & $a$ & 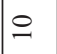 & in & $\infty$ & $\nabla$ & $m$ & $\nabla$ \\
\hline+ & + & + & + & + & + & ' & + & + & + & + & + & + & ' & ' & + & + & ' & + & ' & + & + \\
\hline 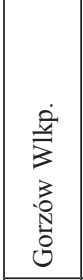 & 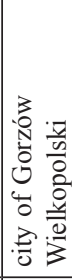 & 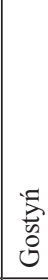 & نُّ & 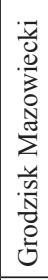 & 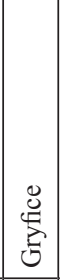 & 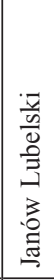 & 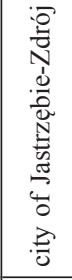 & 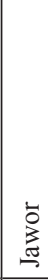 & 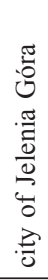 & 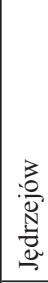 & 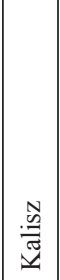 & 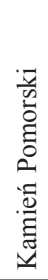 & 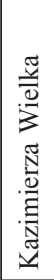 & $\frac{8}{\frac{0}{0}}$ & 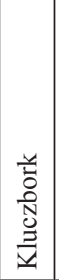 & 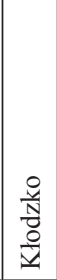 & 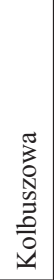 & $\begin{array}{l}\frac{0}{0} \\
\frac{1}{1}\end{array}$ & 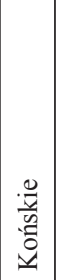 & $\begin{array}{l}\Xi \\
0 \\
0\end{array}$ & 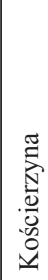 \\
\hline 离 & $\begin{array}{l}\overline{0} \\
\& \\
0\end{array}$ & ষ্ণ & त् & 乯 & 离 & : & 菑 & ڤ్ & 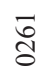 & 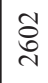 & \&్ & 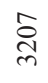 & 館 & $\begin{array}{l}\text { ¿े } \\
\text { ¿ }\end{array}$ & $\underset{-}{ \pm}$ & 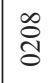 & $\stackrel{\circ}{\infty}$ & \&े & $\begin{array}{l}n \\
\text { \& } \\
\text { N }\end{array}$ & $\stackrel{\circ}{\stackrel{0}{\circ}}$ & $\begin{array}{l}\text { ¿े } \\
\text { సे }\end{array}$ \\
\hline i & $\vec{\sim}$ & $\tilde{\lambda}$ & $\ddot{\sim}$ & $\stackrel{ \pm}{\sim}$ & $\approx$ & $\stackrel{\sim}{\sim}$ & $\hat{\sim}$ & $\stackrel{\infty}{\sim}$ & Әे & ిల & $\vec{m}$ & กี & $m$ & फे & $\tilde{m}$ & $\stackrel{n}{ }$ & $\hat{n}$ & $\stackrel{\infty}{\infty}$ & ले & f & $F$ \\
\hline
\end{tabular}




\section{Conclusions}

Summarising the performed tests, one can conclude that the EwidencjaKIIP collective service is currently made up of only 123 district services, while 17 of them are based on incomplete cadastral data. Spatial distribution of all the districts WMS functioning within the EwidencjaKIIP is presented in Figure 6.

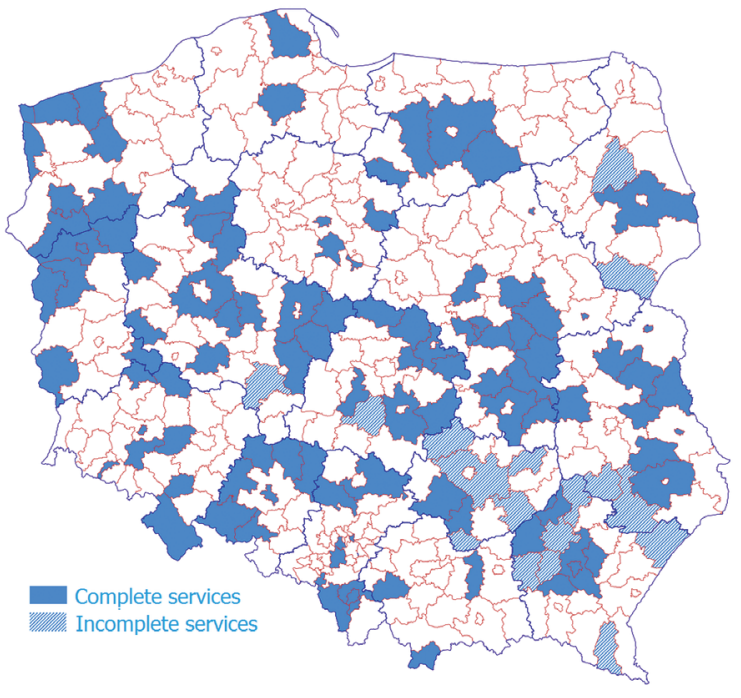

Fig. 6. Map of districts that are part of the EwidencjaKIIP services

Based on the analysis, at least three conclusions can be made in relation to the functioning of the collective service:

1. Despite the span of 10 years since the standard was developed and the first services were published, the collective service today contains only $33 \%$ of all districts. More intensive actions should be taken so that one does not have to wait another 20 years for all district services.

2. When it comes to the operating services, monitoring of their operation should be in place so that proper measures are taken when problems occur.

3. Most services in the collective service work well, but in the case of the services which scored less than 5 points changing of the server or improving transfer parameters should be considered.

The revealed status of the EwidencjaKIIP indicates that data need to be supplemented in the districts where they are incomplete, and that the WMS needs to be launched in the districts that have no such services. Knowing the current status of availability of the district WMS, one can say that the condition of the collective service can be quickly improved by incorporating into it many services that are available but, for some reason, are not part of the collective service. An in-depth 
analysis could be carried out on this, but the most important cause is that frequently districts are not aware of the collective service functioning; it would be advisable to raise their awareness and, at the same time, obtain useful information about the launched services. Actions like that should be taken as fast as possible since the dominant WMS with respect to land parcel data is the service based on cadastral data from the land-parcel identification system LPIS, namely http://mapy.geoportal.gov. pl/wss/service/pub/guest/G2_GO_WMS/MapServer/WMSServer Sadly, the service in question contains many errors, which is illustrated by a piece of data from the Mińsk Mazowiecki district in Figure 7.

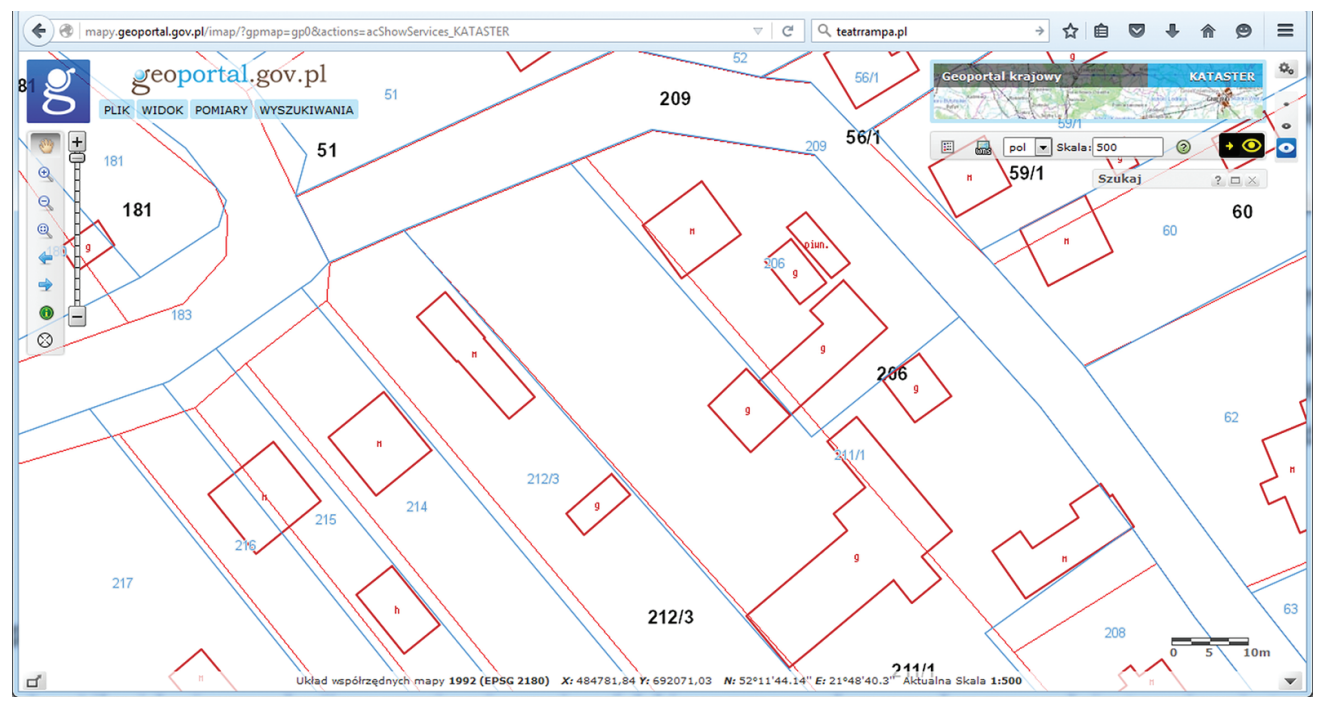

Fig. 7. An example of discrepancies between the so-called cadastral data and the data derived directly from the district

That such state of affairs continues is beyond comprehension; the district in question has had the WMS available since 2007, containing up-to-date cadastral data, and has requested multiple times that GUGiK should disable the publication of erroneous data. Similar efforts have been made by other districts as well, but GUGiK, for reasons best known to themselves, has not removed the incorrect data, thereby intentionally misleading the users of the WMS containing cadastral type data and the users of the geoportal.gov.pl portal, the layer of which, "Cadastral type data", is based on the same invalid LPIS data.

\section{Acknowledgments}

This article is the result of the author's own research in the Department of Geodesy and Cartography, Warsaw University of Technology. 


\section{References}

Izdebski, W. (2014). Koncepcja standaryzacji usług lokalizacji przestrzennej adresów i działek katastralnych. Magazyn Geoinformacyjny GEODETA, 2 (225), 14-18.

Izdebski, W. (2016). Dobre praktyki udziału gmin i powiatów $w$ tworzeniu infrastruktury danych przestrzennych $w$ Polsce. Warszawa: Geo-System Sp. z o.o.

Gaździcki, J. (2016). Real estate cadastre within the spatial information infrastructure in Poland, Roczniki Geomatyki, XIV, 295-303.

Oosterom, P., Groothedde, A., Lemmen, Ch., Molen, P., Uitermark, H. (2009). Land Administration as a Cornerstone in the Global Spatial Information Infrastructure. International Journal of Spatial Data Infrastructures Research, 4, 298-331.

Geoforum.pl (2009). Nowości na Geoportal.gov.pl [http://geoforum.pl/?page=news\&id=5540\&link= Nowo\%C5\%9Bci\%20na\%20Geoportal.gov.pl]

Inspire (2011). Task Force Service Team Technical Guidance for the implementation of INSPIRE View Services. IOC Task Force for Network Services [TechnicalGuidance_ViewServices_v3.0.pdf]

Inspire (2014). Thematic Working Group Cadastral Parcels Data Specification on Cadastral Parcels - Technical Guidelines. INSPIRE Thematic Working Group Cadastral Parcels

GUGiK (2017). http://mapy.geoportal.gov.pl/gpsr-web/gpsr/katalogWMS/KIIPPowiaty 